\title{
The effect of the interest coverage covenants on classification shifting of revenues
}

\begin{abstract}
While prior studies focus on real/accrual-based earnings management and expense misclassification to investigate earnings manipulation in avoiding covenant violations, this paper extends such research in a new direction. In particular, it examines whether firms employ classification shifting of revenues when they are subject to interest coverage EBITDA-based covenants close to their threshold values or limits. This earnings management tool allows firms to increase reported EBITDA by misclassifying non-operating revenues as operating revenues to remain within covenant limits that include EBITDA. Using a sample of 559 UK listed firmyears for the period 2005-2014, it establishes that the use of classification shifting of revenues is high when interest coverage covenants are close to their limits. Further analysis suggests that firms also employ revenue shifting when all their loan covenants are EBITDA-related.
\end{abstract}

Keywords: classification shifting of revenues; interest coverage covenant; debt covenant violations 


\section{Introduction}

Banks impose conditions on loans via covenants to reduce agency costs. Violations of debt covenants give lenders the option of modifying the cost of debt, accelerating the loan repayment schedule, decreasing the availability of credit or restricting capital spending. The Watts and Zimmerman (1986) debt covenant hypothesis states that firms with tight covenant slack $^{1}$ have incentives to manage earnings to avoid these costly actions. To test this hypothesis, a stream of studies investigate whether firms that have tight covenant slack inflate earnings using real/accruals-based earnings manipulation and expense misclassification tools of earnings management (hereafter EM) (e.g. DeFond and Jiambalvo 1994; Dichev and Skinner 2002; Fan, Thomas, and Yu 2019; Franz, HassabElnaby, and Lobo 2014). They establish that firms with tight covenant slack employ these forms of EM.

However, the results of extant studies do not provide a complete picture of managing earnings in the debt contracting setting. This is because, in addition to real/accruals-based EM and expense shifting, firms might employ other manipulation tools to remain within covenant limits. If such tools are available to management, then lenders and investors will not have a broad and comprehensive understanding of firms' EM practices in the context of debt covenants. When management are considering undertaking EM they have to evaluate a number of factors, a significant one being the costs, both direct and indirect, of using a particular EM method. As there are potential high costs associated with using traditional real/accruals EM, this provides a motivation for management to consider if there are alternative less costly and feasible techniques that allow them to manage earnings. Collectively, these factors suggest that it is important to identify other possible manipulation methods that firms with tight covenant may use.

\footnotetext{
${ }^{1}$ Tight covenant slack is defined as situations where a company is close to its covenant threshold value.
} 
This aim of this paper is to investigate an alternative EM tool - classification shifting of revenues - which has not previously been explored in the debt contracting setting. Specifically, it examines whether firms employ this type of manipulation tool when they have tight EBITDA-based covenant slack. Firms engage in classification shifting of revenues by misclassifying non-operating revenues as operating revenues (Malikov, Manson, and Coakley 2018). This form of EM increases operating revenues and thereby EBITDA (earnings before interest, taxes, depreciation and amortization) but it does not change net income. Therefore, using classification shifting of revenues may help firms to remain within EBITDA-based covenant limits.

Classification shifting of revenues may be a preferable EM method to use by firms with tight EBITDA-based covenant slack as it enjoys several advantages compared to accrualsbased (real) EM and expense misclassification. First, unlike accruals-based (real) EM, revenue misclassification attracts less auditor scrutiny because it has no effect on the bottom line income. Where audit clients engage in manipulating their financial statements by violating GAAP (e.g. accruals EM) auditors might face reputational risk and litigation costs and therefore have greater incentives to object to these violations. Classification shifting of revenues also has no tax implications, no accruals that later reverse, and no negative future firm performance implications relative to real and accruals EM. For instance, firms using real EM make suboptimal operating decisions which are likely to place the firm in a less competitive situation in the future. Second, unlike expense misclassification, revenue shifting enables firms to simultaneously achieve more objectives. If firms with tight EBITDA-related covenant slack decide to employ revenue shifting, this will allow them not only to avoid covenant violations but also to meet earnings and sales revenue forecasts as well as to increase their market 
valuation. $^{2}$ All these objectives are unlikely to be achieved via expense shifting and furthermore, firms do not always have scope for employing a technique such as expense misclassification. This is because firms employ expense shifting when they have naturally occurring non-recurring expenses - income-decreasing special items - which may not occur every year (e.g. Fan, Barua, Cready, and Thomas 2010; McVay 2006).

We examine whether firms employ classification shifting of revenues when they have tight EBITDA-based covenant slack in the context of the UK for several reasons. Firstly, bank debt is the main source of borrowing in the UK (Marshall, McCann, and McColgan 2019) where EBITDA-based covenants are the most commonly used covenants (e.g. Christensen, Lee, and Walker 2009; Moir and Sudarsanam 2007). For example, Christensen et al. (2009) document that the interest coverage (EBITDA-based) covenant is the most common one in the UK and is included in virtually all UK debt contracts. This offers scope for studying whether firms employ revenue shifting to remain within covenant limits. Secondly, the consolidated financial statements of UK companies have to be prepared in compliance with IFRSs. These standards provide scope for management to misclassify income statement line items (Malikov et al. 2018; Zalata and Roberts 2017). Particularly pertinent to this study is that IAS 18 - Revenue focused more on the measurement of revenue rather than its disclosure. Having such flexibility in terms of disclosure makes the UK an interesting setting for examining whether firms avoid covenant violations by using revenue shifting. Thirdly, the UK has a creditor-friendly bankruptcy code which means that default events result in the control rights over the borrowing firm being transferred to banks (Acharya, Sundaram, and John 2011). A covenant violation in the UK entitles the lending bank - and by extension all banks through cross-default clauses - to place

\footnotetext{
${ }^{2}$ Ertimur, Livnat, and Martikainen (2003) and Marguardt and Wiedman (2004) show that investors value a dollar of operating revenues surprises greater than a dollar decrease in operating expenses.
} 
that firm directly into receivership and liquidate its assets. ${ }^{3}$ This suggests that UK firms have strong incentives not to be in technical default which offers scope to examine whether they achieve this by engaging in classification shifting of revenues.

Our empirical analysis uses company annual reports to identify UK firms with private debt covenants. Similar to prior studies, we find that the interest coverage EBITDA-based covenant is the most commonly used UK covenant and therefore this covenant is employed in our analysis. Using a sample of UK firms with interest coverage covenants over the period 20052014, the results show that the use of classification shifting of revenues is high when the interest coverage covenant slack is tight. This supports the debt covenant hypothesis for this alternative form of EM. Further analysis suggests that firms also employ revenue shifting when all their loan covenants are EBITDA-related. This implies that misclassification of revenue items depends on the centrality of EBITDA as a performance metric in loan contracts. Overall, the results suggest that the level of the interest coverage covenant slack provides the motivation for firms to engage in classification shifting of revenues.

This study contributes to two strands of the literature. First, it extends the debt covenant hypothesis literature by providing evidence that firms with tight covenant slack employ not only real/accrual-based EM or expense misclassification (e.g. Fan et al. 2019; Franz et al. 2014) but also classification shifting of revenues. The results suggest that the latter is an important EM technique used to remain within covenant limits. It provides new insights into firms' EM practices in the context of debt covenants. The results can help inform lenders of the need to monitor the company's revenue stream and of including an appropriate definition of revenue within any loan agreement. Our study underlines the need for a tighter definition of revenue

\footnotetext{
${ }^{3}$ This is not the case in all countries. For example, the USA has a debtor-friendly bankruptcy code which means that banks in the USA cannot place firms directly into liquidation if the firms file for Chapter 11 bankruptcy protection (Acharya et al. 2011; Li, Lou, and Vasvari 2015). The latter gives firms 120 days to recapitalize and potentially find a solution to their financial difficulties.
} 
and thereby provides some justification for the issue of IFRS 15, Revenue from Contracts with Customers, by the IASB.

Second, it extends the classification shifting of revenues literature by providing evidence that having tight EBITDA-related covenant slack in place is one motivation for firms to misclassify revenue items. To our knowledge, this paper is the first to document these results. Prior studies provide evidence that firms show non-operating revenues such as transitory gains as part of operating activities but they do not examine why firms engage in misclassification of revenue items with the exception of Hsu and Kross (2011). They document that firms show transitory gains as part of operating revenues to meet/beat zero operating profit or prior period operating profit. However, this is just one motivation for misclassifying revenue items and therefore it is important to examine other incentives behind this EM form. In this sense, our results are important as they add to our understanding of revenue misclassification by showing that credit market incentives motivate firms to employ the technique.

This study proceeds as follows. Section 2 reviews the related literature and develops the main hypothesis. Section 3 describes the sample selection and the research design. Section 4 analyses the empirical results and Section 5 concludes.

\section{Literature review and hypothesis development}

\subsection{Literature review}

The debt covenant hypothesis has been mainly tested using real/accruals-based EM forms of manipulation in the USA. Sweeney (1994) finds that firms are more likely to use accruals management when they are approaching violations of debt covenants. DeFond and Jiambalvo (1994) document that accruals EM is positive in the year prior to violation. In terms of the year of violation, they find the use of such EM tools only after controlling for management changes and auditor going concern qualifications. Franz et al. (2014) extend these studies by examining whether firms with tight covenant slack use real EM in addition to accruals management. They 
find for a sample of US Dealscan firms with a tight covenant slack for the current ratio covenant employ real EM. ${ }^{4}$ The recent study by Fan et al. (2019) documents that firms with tight EBITDA-based covenant slack also employ expense misclassification.

Prior UK studies analyse which accounting and other debt-based covenants are used in bank debt contracts but do not formally or directly test the debt covenant hypothesis. Citron (1992) investigates the types of accounting-based covenants using 25 UK bank loan contracts and 13 contract templates. He finds that interest coverage, net worth and gearing are the most frequently used accounting-based covenants. Day and Taylor (1996) interview 44 major UK corporate treasurers and obtain findings that are consistent with Citron (1992). Chatterjee (2006) investigates performance pricing in debt contracts using a sample of 64 firms. He documents that interest coverage and debt to EBITDA are the dominant debt covenants in UK debt contracting. Moir and Sudarsanam (2007) in a survey of private debt contracts based on 72 large non-financial UK companies report that interest coverage is the most frequently occurring debt covenant, in line with the more recent study by Christensen et al. (2009). Overall, the literature affirms that the interest coverage EBITDA-based covenant is the most widely used covenant in UK debt contracting (e.g. Taylor 2013).

In sum, prior studies mainly focus on costly manipulation methods, real/accruals-based EM, to examine the debt covenant hypothesis. However, firms may have scope to use other EM methods which are not as costly as real/accruals-based EM and therefore the results of existing studies may not provide a comprehensive picture of firms' manipulation practices in the debt contracting setting. In this sense, it is important to identify other possible manipulation methods that firms may employ to remain within covenant limits. In this paper, we focus on one form of EM - classification shifting of revenues - to examine whether firms use it to avoid breaching the interest coverage covenants. The classification shifting of revenues literature

\footnotetext{
${ }^{4}$ Similar results are found by Kim, Lisic, and Pevzner (2010) who employ net worth covenants.
} 
provides evidence that firms misclassify revenue items but they do not examine why firms engage in such misclassifications. ${ }^{5}$ Investigating the proposed research question allows us to determine the motivations behind using this manipulation method.

\subsection{Hypothesis development}

Extant studies show that covenant violations increase the cost of debt, accelerate the loan repayment schedule, decrease the availability of credit (Roberts and Sufi 2009), restrict capital spending (Chava and Roberts 2008), lead to legal actions, reduce shareholder payouts, and increase CEO turnover (Nini, Smith, and Sufi 2012). A covenant violation is especially costly in countries like the UK where banks have rights to liquidate firms' assets that violate their debt covenants (Davydenko and Franks 2008; Deakin, Mollica, and Sarkar 2017). Firms might employ several options in seeking to avoid these costs. One option is that they may renegotiate their covenants before actually breaching them. They, however, may not be successful using this option because creditors exercise their control rights in a state-contingent manner. For instance, creditors may have little incentive to relax EBITDA-based covenant limits if they do not believe that the borrower is likely to improve its profitability in the future (Denis and Wang 2014). In support of these arguments, Godlewski (2015) shows that debt renegotiations are not common in the UK.

Therefore, firms might resort to other options such as managing earnings to avoid EBITDA-based covenant violations. They are likely to make a decision on whether to use this option by comparing the costs of violation versus the costs of engaging in EM. Extant studies suggest that managers appear to find covenant violations more costly than EM (e.g. Franz et al. 2014; Kim et al. 2010). The extent of EM is likely to depend on whether the accounting market where the firm is operating is strictly regulated. For example, the UK accounting market

\footnotetext{
${ }^{5}$ One exception for this is the study by Hsu and Kross (2011) who provide evidence that one motivation for showing non-operating revenues, transitory gains, as part of operating revenues is to meet/beat operating earnings benchmarks.
} 
is not strictly regulated because it does not have regulatory organizations like the SEC (Securities and Exchange Commission) in the USA that issues cautions to warn investors about potential manipulation tools whereas in the $\mathrm{UK}$, the primary regulator is the Financial Reporting Council which through its conduct committee reviews corporate financial statements mainly to ensure they are in compliance with the law. Furthermore, extant studies suggest that UK firms are subject to considerably lower litigation risk than their US counterparts (Seetharaman, Gul, and Lynn 2002; Zalata and Roberts 2016). Collectively, the above arguments suggest that a covenant violation is more costly than managing earnings particularly in countries like the UK and thus firms have incentives to employ EM to remain within interest coverage EBITDA-based covenant limits.

Firms are likely to use those manipulation methods that help them avoid infringing an EBITDA-based covenant. Classification shifting of revenues might be one such EM tool that is employed to avoid debt covenant violations. This is because it enables firms to improve EBITDA by misclassifying non-operating revenues as operating revenues and thereby potentially remain within covenant limits. The debt contractual definitions of EBITDA, in general, do not include revenues from non-operating activities. For example, Li (2016) finds that the contractual definitions of EBITDA-based debt covenants usually exclude gains from special items. Appendix 1 provides the illustrative format of the income statement. It shows that EBITDA includes revenues from operating activities but not from non-operating activities.

We, therefore, expect that firms with tight interest coverage EBITDA-based covenant slack are likely to employ revenue shifting to avoid covenant violations. This form of EM has no accruals that later reverse and no negative future firm performance implications unlike accruals and real EM, respectively. Furthermore, classification shifting of revenues allows firms to inflate operating profit via increasing sales and decreasing non-operating revenues unlike other EM techniques (e.g. expense misclassification). This is important as firms have 
incentives to decrease non-recurring gains and to increase operating revenues to influence investors' perceptions by providing a signal that their revenues are mainly based on recurring operations (e.g. Marguardt and Wiedman 2004; Weiss 2001).

The following overarching hypothesis (stated in alternative form) follows from the above discussion:

Hypothesis: Firms engage in classification shifting of revenues when they have tight interest coverage covenant slack.

\section{Sample selection and research design}

\subsection{Sample selection}

We start the sample selection with all UK (dead and alive) ${ }^{6}$ listed firms in Compustat Global for the period between 2005 and 2014. The sample period begins in 2005 as UK listed firms were required to follow IFRS from $2005 .{ }^{7}$ Following extant studies, financial and utility firms are excluded as the former have a different financial reporting environment and the latter have more predictable earnings growth. Furthermore, firm-year observations are excluded for which the data is not available to calculate EM measures. This yields a sample of 5,827 firm-year observations, capturing 1,124 firms. To obtain covenant information, we manually check all these 1,124 firms' annual reports during our sample period. Consequently, we find 1,272 firmyear observations with debt covenants, comprising 302 firms.

[Insert Table 1 about here]

Table 1 shows the summary of covenant restrictions for our sample firm-years. We find that the interest coverage EBITDA-based covenant is the most frequently used covenant and is included in virtually all UK debt contracts as 1,129 firm-years out of 1,272 include such type

\footnotetext{
${ }^{6}$ Dead firms are included across the test period to avoid survivorship bias.

${ }^{7}$ Note, UK firms quoted on the Alternative Investment Market were required to follow IFRS from 2007. Therefore, for these firms, our sample period begins in 2007.
} 
of covenant. This is in line with extant UK studies (Moir and Sudarsanam 2007; Christensen et al. 2009). Thus, we employ the interest coverage EBITDA-based covenant in our main analysis. Our final sample with interest coverage covenants consists of 559 firm-years, covering 126 firms since we lose 570 firm-years $^{8}$ with interest coverage covenants due to threshold values not being stated in the annual report.

\subsection{Interest coverage covenant slack}

Following Franz et al. (2014), we measure interest coverage covenant slack as follows:

$$
\text { IC_SLACK } K_{i, t}=\frac{\text { Actual }_{i, t}-\text { Threshold }_{i, t}}{\text { Threshold }_{i, t}}
$$

where $A_{c t u a l}, t$ is the actual value of the interest coverage covenant for firm $i$ in year $t$; Threshold $_{i, t}$ is the threshold value of the interest coverage covenant. The actual value of the interest coverage covenant is calculated using the standard definition specified by Demerjian and Owens (2016) as EBITDA divided by interest expense.

The measurement of covenant slack may be subject to measurement error (Beatty, Weber, and Yu 2008; Rhodes 2016). This is because some lenders may adjust GAAP numbers when they define debt covenant thresholds. Thus, the definition of interest coverage may vary across different borrowers and debt contracts. We mitigate this measurement error by defining firms that have interest coverage covenant slack within the bottom tercile ${ }^{9}$ of the full sample as those with tight covenant slack while all other firms are defined as having loose slack in the spirit of Rhodes (2016).

\subsection{Measuring classification shifting of revenues}

\footnotetext{
${ }^{8}$ While annual reports highlight that these firms are subject to interest coverage covenants, they do not reveal their threshold values.

${ }^{9}$ Our results do not change if we define tight covenant slack as firms that have interest coverage covenant slack within the lower quartile.
} 
We follow Malikov et al. (2018) in measuring classification shifting of revenues. They posit that unexpected operating revenues (reported operating revenues (sales and other operating revenues) less expected operating revenues) in year $t$ increase as non-operating revenues in year $t$ decrease if managers use classification shifting of revenues. We employ the following model proposed by Malikov et al. (2018) to estimate the expected level of operating revenues:

$$
\frac{O R_{i, t}}{A T_{i, t-1}}=\alpha_{0}+\beta_{1} \frac{1}{A T_{i, t-1}}+\beta_{2} \frac{O R_{i, t-1}}{A T_{i, t-2}}+\beta_{3} M T B_{i, t-1}+\beta_{4} \frac{A R_{i, t-1}}{A T_{i, t-2}}+\beta_{5} \frac{A R_{i, t}}{A T_{i, t-1}}+e_{i, t}
$$

where $O R_{i, t}$ is operating revenues for firm $i$ in year $t$, defined as the sum of sales revenue and other operating revenues; $M T B_{i, t-1}$ is the market to book ratio; $A T_{i, t-1}$ is total assets; $A R_{i, t}$ is accounts receivable.

The model includes lagged operating revenues $\left(O R_{i, t-1}\right)$ since operating revenues tend to be persistent. Lagged market-to-book ratio $\left(M T B_{i, t-1}\right)$ is included to control for growth opportunities because lagged operating revenues are likely to be a noisy proxy for predicting high growth firms' future operating revenues. Since past accruals negatively affect future earnings performance (e.g. McVay 2006; Sloan 1996), lagged accounts receivable $\left(A R_{i, t-1}\right)$ are included to capture the information content of prior-year accounts receivable for current-period revenues. Current accounts receivable $\left(A R_{i, t}\right)$ controls for extreme operating performance because unusually high operating revenues are likely to be associated with a large increase in accounts receivable. Finally, a scaled intercept is added to avoid a spurious correlation between scaled accounts receivable and operating revenues due to the variation in the scaling variable, total assets.

Equation (2) is estimated cross-sectionally for each industry-year to control for macroeconomic and industry shocks. ${ }^{10}$ Unexpected operating revenues are defined as the

\footnotetext{
${ }^{10}$ We estimate the model cross-sectionally for each industry-year using all UK firms included in Compustat Global. We employ the Global Industry Classification Scheme and require, following Athanasakou, Strong, and Walker (2009), at least 6 observations per industry-year to ensure that we have sufficient data for the estimation of classification shifting of revenues EM measure.
} 
difference between reported and expected operating revenues, where the latter are estimated using the coefficients from model (2). ${ }^{11}$

\subsection{Regression model}

Our hypothesis predicts that firms engage in classification shifting of revenues when they have tight interest coverage covenant slack. To test this, we use the following regression equation:

$$
\begin{aligned}
& U E_{-} O R_{i, t}=\alpha_{0}+\alpha_{1} N O R_{i, t}+\alpha_{2} T I G H T_{-} I C_{-} S L A C K_{i, t}+\alpha_{3} N O R_{i, t} \times T I G H T_{-} I C_{-} S L A C K_{i, t}+\alpha_{4} A_{-} C F O_{i, t}+ \\
& \alpha_{5} N O R_{i, t} \times A_{-} C F O_{i, t}+\alpha_{6} A_{-} D I S X_{i, t}+\alpha_{7} N O R_{i, t} \times A_{-} D I S X_{i, t}+\alpha_{8} A_{-} P R O D_{i, t}+\alpha_{9} N O R_{i, t} \times \\
& A_{-} P R O D_{i, t}+\alpha_{10} A_{-} W C A_{i, t}+\alpha_{11} N O R_{i, t} \times A_{-} W C A_{i, t}+\alpha_{12} C S_{i, t}+\alpha_{13} N O R_{i, t} \times C S_{i, t}+ \\
& \alpha_{14} D_{S S T_{i, t-1}}+\alpha_{15} \operatorname{NOR}_{i, t} \times \operatorname{DIST}_{i, t-1}+\alpha_{16} \operatorname{LOSS}_{i, t}+\alpha_{17} N_{O R} R_{i, t} \times \operatorname{LOSS}_{i, t}+\alpha_{18} \operatorname{SIZE}_{i, t}+ \\
& \alpha_{19} N O R_{i, t} \times S I Z E_{i, t}+\varepsilon_{i, t}
\end{aligned}
$$

In the model, $U E_{-} O R_{i, t}$ is unexpected operating revenues for firm $i$ in year $t . N O R_{i, t}$ is nonoperating revenues, calculated as foreign exchange gains plus income-increasing special items and discontinued operations plus interest and related income plus other non-operating income including rental income divided by lagged total assets. The regression of $U E_{-} O R_{i, t}$ on $N O R_{i, t}$ provides the basis for testing classification shifting of revenues. TIGHT_IC_SLACK $K_{i, t}$ is our test variable that is equal to one for firms with tight interest coverage covenant slack, and zero otherwise. The interaction of $N O R_{i, t}$ with $T I G H T_{-} I C_{-} S L A C K_{i, t}$ shows the effect of tight interest coverage covenant slack on classification shifting of revenues. Our hypothesis predicts a negative coefficient on $N O R_{i, t} \times T I G H T \_I C \_S L A C K_{i, t}$ in regression (3).

The model includes several control variables. First, we control for firms' other EM practices using the following variables: $A_{-} C F O_{i, t}$ is abnormal levels of cash flows from operations. $A_{-} D I S X_{i, t}$ is abnormal levels of discretionary expenses. $A_{-} P R O D_{i, t}$ is abnormal levels of production costs. $A_{-} W C A_{i, t}$ is abnormal levels of working capital accruals. $C S_{i, t}$ is

\footnotetext{
${ }^{11}$ In other words, unexpected operating revenues are measured as the residuals from the regression model in equation (2).
} 
equal to one for firms that have positive unexpected core earnings and income-decreasing special items, and zero otherwise. $A_{-} C F O_{i, t}, A_{-} D I S X_{i, t}$ and $A_{-} P R O D_{i, t}$ are the measures of real EM (Roychowdhury 2006), $A_{-} W C A_{i, t}$ is the measure of accruals $\mathrm{EM}^{12}$ (Dechow and Dichev 2002), and $C S_{i, t}$ is the proxy of classification shifting of expenses (Joo and Chamberlain 2017) (see Appendix 2 for the detailed explanations of how other EM measures are estimated). These variables are included as main effects and as interactions with $N O R_{i, t}$ because the use of classification shifting of revenues may be affected by other types of EM tools. Abernathy, Beyer, and Rapley (2014), Fan et al. (2010), and Zang (2012) find that when firms increase using one type of EM they decrease using the other ones while Fan and Liu (2017) document some evidence that firms employ EM tools simultaneously. Moreover, since prior studies show the existence of accruals/real EM and expense misclassification, controlling for these methods of EM ensures that our results are due to revenue misclassification.

Second, we control for firm characteristics using the following variables: $D I S T_{i, t-l}$ reflects the value of the Taffler (1983) Z-score, with lower values showing a higher probability of default. Prior studies show that the use of EM increases as the probability of default becomes higher (Butler, Leone, and Willenborg 2004; Jacoby, Li, and Liu 2019; Nagar and Sen 2016; Walker 2013). Therefore, $D I S T_{i, t-1}$ and its interaction with $N O R_{i, t}$ are added to ensure that our results are due to engaging in revenue shifting to avoid covenant violations and not to firms suffering financial distress. We include a dummy variable for firms that report a loss $\left(L O S S_{i, t}\right)$ as well as its interaction with $N O R_{i, t}$ as operating revenues rather than earnings are value relevant for firms reporting losses (Callen, Robb, and Segal 2008; Kama 2004) and thus they are likely to employ revenue shifting to overestimate operating revenues. Large firms are more likely to have revenues from non-operating activities which offer them greater opportunity to

\footnotetext{
12 The results do not change if we employ other measures of accruals EM such as total discretionary accruals (e.g. Peasnell, Pope, and Young 2000; Peasnell, Pope, and Young 2005).
} 
engage in revenue misclassification. Alternatively, such firms may not employ classification shifting of revenues because the political cost hypothesis states that large firms are subject to extensive government scrutiny (Watts and Zimmerman 1990). As such, we control for large firms' classification shifting of revenues practices by adding a dummy variable, $S I Z E_{i, t}$, that is equal to one for firms that have a natural logarithm of sales revenue within the top tercile of the full sample and zero otherwise, and its interaction with $N O R_{i, t}$. Finally, year dummies are included to control for timing effects. We use standard errors clustered by firm to control for time-series dependence in our panel model following Petersen (2009).

\section{Empirical results}

\subsection{Descriptive statistics}

Table 2, Panels A and B indicate the descriptive statistics for the main variables of the full sample and the firms with tight and loose interest coverage covenant slack, respectively. Panel A indicates that the median (mean) value of the interest coverage covenant threshold (IC_COV) is 3.5 (3.443). The interest coverage covenant slack $\left(I C \_S L A C K\right)$ has a median value of 1.778 . The corresponding mean exceeds its median implying that it is right skewed. The median (mean) of unexpected operating revenues $\left(U E \_O R\right)$ is $-0.006(-0.002)$ and the median (mean) of non-operating revenues $(N O R)$ is $0.003(0.013)$. Panel B shows that the median (mean) of the interest coverage covenant slack, as expected, is significantly lower for firms with tight covenant slack relative to their counterparts with loose covenant slack. Firms with tight covenant slack have significantly larger median (mean) non-operating revenues and lower median (mean) unexpected operating revenues than their counterparts with loose covenant slack. Regarding real/accruals EM and expense misclassification measures, we find that firms with tight covenant slack have significantly lower median (mean) abnormal levels of cash flows from operations $\left(A \_C F O\right)$ and larger abnormal levels of production costs $\left(A \_P R O D\right)$ relative to firms with loose covenant slack. The results suggest that firms with tight covenant slack use 
more real EM given that firms with abnormally high production costs or with abnormally low cash flows from operations are regarded as engaging in real activities manipulation (e.g. Gunny 2010; Roychowdhury 2006). This supports extant studies that examine the debt covenant hypothesis employing real EM in the context of US firms (e.g. Franz et al. 2014).

[Insert Table 2 about here]

Table 3 displays Pearson correlation coefficients for the main variables. We observe that there is a significant and negative correlation between unexpected operating revenues (UE_OR) and non-operating revenues $(N O R)$. Other significant correlations include those between abnormal levels of cash flows from operations (A_CFO) (abnormal levels of discretionary expenses $\left.\left(A \_D I S X\right)\right)$ and abnormal levels of production costs $\left(A \_P R O D\right)$, in line with the corresponding correlations reported in existing studies (e.g. Roychowdhury 2006; Zang 2012). The results indicate that when abnormal levels of production costs increase abnormal levels of cash flows from operations (discretionary expenses) decrease.

[Insert Table 3 about here]

\subsection{Interest coverage EBITDA-related covenant measure}

Table 4 provides regression results for testing whether firms engage in classification shifting of revenues when they have tight interest coverage covenant slack. The table shows that the $N O R \times T I G H T \_I C \_S L A C K$ coefficient is significantly negative for unexpected operating revenues. This indicates that firms employ classification shifting of revenues when they have tight interest coverage covenant slack. The coefficient for NOR is -0.771 and that on NOR $\times$ TIGHT_IC_SLACK is -1.270 and both coefficients are significant. Thus, the overall effect of non-operating revenues for firms with tight interest coverage covenant slack is -2.041 (-0.7711.270; $\mathrm{p}=0.002$ ). This suggests that when borrowers are close to violating an interest coverage covenant their managers engage to a larger extent in classification shifting of revenues which supports our hypothesis. 
[Table 4 around here]

\subsection{Other EBITDA-related covenant measures}

We also investigate the effect of other EBITDA-related covenant measures on revenue misclassification. To do so, we first examine whether firms use classification shifting of revenues when all their loan covenants are EBITDA-related. One can argue that EBITDA particularly becomes a more important performance metric in loan contracts when all firms' covenants are EBITDA-related rather than being a mixture of both EBITDA- and nonEBITDA-based covenants. Inflating EBITDA via revenue shifting can allow firms with EBITDA-related covenants to remain within all their covenant limits unlike their counterparts with both EBITDA- and non-EBITDA-based covenants. The implication is that firms are more likely to employ misclassification of revenue items when all their loan covenants are EBITDArelated.

Furthermore, undertaking this further analysis enables us to consider all UK listed firms with covenants details as it does not require the availability of threshold values. Consequently, this analysis increases our sample size from 559 firm-years (126 unique firms) to 1,272 firmyears (302 unique firms). We use the following variable to test revenue shifting practices of firms with only EBITDA-related covenants. EBITDA_ALL is equal to one for firms that have all their loan covenants EBITDA-related ${ }^{13}$, and zero otherwise. ${ }^{14}$ We replace the tight interest coverage covenant slack (TIGHT_IC_SLACK) variable with EBITDA_ALL in regression (3) and rerun it. Table 5, column (1) shows that the coefficient on NOR is significantly positive (0.922) but that on $N O R \times E B I T D A \_A L L$ is significantly negative (-1.566), giving a net coefficient of $-0.644(0.922-1.566 ; \mathrm{p}=0.081)$ on $N O R$ for firms with only EBITDA-related

\footnotetext{
${ }^{13}$ The following covenants are regarded as EBITDA-related covenants: 1) interest coverage, 2) debt to EBITDA, 3) fixed charge coverage, 4) debt service coverage, 5) EBITDA, and 6) EBITDA to net debt. In our sample, 842 firm-year observations out of 1,272 have only EBITDA-related covenants.

${ }^{14}$ The results do not change if we use a continuous variable that is defined as the number of EBITDA-related covenants divided by the number of all financial covenants that a firm has in a specific year.
} 
covenants. The results suggest that borrowers employ revenue shifting when they have only EBITDA-related covenants in their loan contracts.

[Table 5 around here]

Second, we examine the effect of tight debt to EBITDA covenant slack on classification shifting of revenues. Table 1 shows that the debt to EBITDA covenant in the UK is the second most frequently used covenant after the interest coverage. ${ }^{15}$ Therefore, it would be interesting to test whether firms also engage in revenue misclassification when they have tight debt to EBITDA covenant slack. To test this, we create an indicator variable, TIGHT_DE_SLACK, that is equal to one for firms that have tight debt to EBITDA covenant slack and zero otherwise, and use it to replace TIGHT_IC_SLACK in regression (3). We define firms with tight debt to EBITDA covenant slack as those in the bottom tercile along similar lines to tight interest coverage covenant slack. Table 5, column (2) indicates that while the coefficient on NOR is positive $(0.037)$ but insignificant, the coefficient on NOR $\times$ TIGHT_DE_SLACK is significantly negative (-1.256), yielding a significantly negative overall coefficient on NOR for firms with tight debt to EBITDA covenant slack $(0.037-1.256=-1.219 ; \mathrm{p}=0.040)$. This implies that firms employ revenue shifting when they have tight debt to EBITDA covenant slack. Overall, these and the previous results suggest that, when borrowers are close to violating EBITDA-related covenants, managers engage in classification shifting of revenues.

\subsection{Robustness tests}

\subsubsection{Controlling for corporate governance}

Prior studies provide evidence that the use of earnings management depends on the strength of corporate governance (e.g. Klein 2002; Lin and Hwang 2010; Zalata and Roberts 2016). They find that audit committee size and audit committee independence as well as board

\footnotetext{
${ }^{15}$ As can be seen in Table 1, the use of other covenants is not really common in the UK and therefore we do not consider them.
} 
independence curb manipulation methods such as accruals EM and expense misclassification. It is possible that corporate governance may also affect classification shifting of revenues which in turn may drive our main results. To control for this, we use the following two variables for which data are hand collected from the annual reports. $A U D C$ is equal to one if the size of the audit committee is greater than the sample median and all directors on the audit committee are independent, and zero otherwise. BIND is equal to one if the percentage of independent board members is more than the sample median, and zero otherwise. We add these variables as main effects and as interactions with non-operating revenues to regression (3) and rerun it. Table 6 shows that the coefficient for NOR is significantly negative $(-0.827)$ but that on NOR $\times A U D C$ is significantly positive (1.384). The implication is that firms with a strong audit committee do not employ revenue shifting as the overall coefficient on NOR for firms with large audit committees where all directors are independent is $0.557(-0.827+1.384 ; \mathrm{p}=0.445)$. The coefficient on $N O R \times B I N D$ is insignificant, implying that board independence does not affect classification shifting of revenues. More importantly, we find that the coefficient on NOR $\times$ TIGHT_IC_SLACK is significantly negative (-1.745), giving a net coefficient of -2.572 (0.827-1.745; $\mathrm{p}=0.000)$ on NOR for firms with tight interest coverage covenant slack. These findings suggest that our main results are robust to controlling for corporate governance.

[Table 6 around here]

\subsubsection{Excluding financial crisis period}

Existing studies provide inconclusive results on the use of earnings management during the financial crisis period (e.g. Cohen and Zarowin 2007; Kousenidis, Ladas, and Negakis 2013). Moreover, debt contract designs during this time might have different features (Demerjian 2011). As our sample spans the recent financial crisis period (2008-2009 (Beccalli, Bozzolan, Menini, and Molyneux 2015)), the primary results might not be based on a homogenous sample. We, therefore, exclude the crisis period from our sample and rerun the main analysis. 
Table 7 indicates that while the coefficient on NOR is negative (-0.932) but insignificant, the coefficient on NOR $\times$ TIGHT_IC_SLACK is significantly negative (-1.704), yielding a significantly negative overall coefficient on $N O R$ for firms with tight interest coverage covenant slack $(-0.932-1.704=-2.636 ; \mathrm{p}=0.001)$. These results suggest that firms employ classification shifting of revenues when they have tight interest coverage covenant slack, consistent with our primary findings.

[Table 7 around here]

\subsubsection{Alternative measures of unexpected operating revenues}

The main analysis measures unexpected operating revenues using the model proposed by Malikov et al. (2018). They include current-year accounts receivable in their model to control for extreme operating performance. On one hand, the inclusion of this variable is important because it includes receivables both from sale revenues and from other operating revenues. On the other hand, the inclusion of accounts receivable may affect the association between nonoperating revenues and unexpected operating revenues since it may also include receivables from non-operating revenues. Furthermore, their model includes lagged accounts receivable to control for the effect of past receivables on future earnings performance. However, it can be argued that they may affect future cash flows rather than future operating revenues. Thus, we examine the validity of our primary results by using two alternative measures of unexpected operating revenues. Under the first alternative measure, unexpected operating revenues are estimated by replacing lagged and current-year accounts receivable with lagged and currentyear trade receivables in model (2). This is because trade receivables do not include receivables from non-operating revenues. Under the second alternative measure, unexpected operating revenues are estimated by including only current-year trade receivables instead of lagged and current-year accounts receivable in model (2) since past receivables may not affect future operating revenues. We rerun our main analysis using these two alternative measures of 
unexpected operating revenues. The results (not tabulated) suggest that our main findings are not sensitive to the alternative measures of unexpected operating revenues.

\section{Conclusion}

This paper examines whether firms engage in classification shifting of revenues when they have tight EBITDA-based covenant slack. Prior studies have examined this issue by using real/accruals-based earnings management and expense misclassification tools of earnings manipulation. Classification shifting of revenues is a form of earnings manipulation where operating revenues and thereby EBITDA are increased. Therefore, using classification shifting of revenues may help firms to remain within EBITDA-based covenant limits.

Our empirical analysis uses company annual reports to identify UK firms with private debt covenants for the 2005-2014 time period. We find that the interest coverage EBITDA-based covenant is the most commonly employed UK covenant and thus this covenant is used in our analysis. The results show that the use of classification shifting of revenues is high when interest coverage covenant slack is tight, in line with the debt covenant hypothesis for classification shifting of revenues. Further analysis reveals that firms also engage in revenue shifting when all their loan covenants are EBITDA-related. This suggests that misclassification of revenue items depends on how central EBITDA is as a performance metric in loan contracts. Overall, the results provide new insights into firms' earnings manipulation practices in the context of debt covenants by showing that firms with tight covenant slack employ not only real/accrual-based earnings management or expense misclassification (e.g. Fan et al. 2019; Franz et al. 2014) but also classification shifting of revenues.

The findings of this paper have important implications for capital providers. They suggest that lenders and investors need to have an awareness of the possibility of a firm inflating operating revenues via classification shifting when it is subject to EBITDA-based covenants close to their threshold values or limits. This implies that lenders need not only to monitor the 
company's traditional real/accruals earnings management but also to monitor its revenue stream and to include an appropriate definition of revenue within any loan agreement. The paper underlines the need for a tighter definition of revenue and thereby provides some justification for the issue of IFRS 15, Revenue from Contracts with Customers, by the IASB. The results of this paper also provide evidence that the Financial Reporting Council perhaps, needs to follow the SEC in the US and adopt a more aggressive approach in penalising companies that engage in earnings management (Evans, Houston, Peters, and Pratt 2015). Consequently, our results can help lenders, investors and regulators to have a broad and comprehensive understanding of firms' earnings management practices in the context of debt covenants. 


\section{Acknowledgement}

We are grateful to four anonymous referees for their helpful and constructive comments. These have helped us to improve the content and exposition of the paper.

\section{Funding}

Coakley gratefully acknowledges support from grant number ES/L011859/1, from the Business and Local Government Data Research Centre, funded by the Economic and Social Research Council. 
Table 1

Summary of debt covenant restrictions

\begin{tabular}{lcc}
\hline Covenants & Firm-year observations & Number of firms \\
\hline Interest Coverage & 1,129 & 263 \\
Debt to EBITDA & 952 & 226 \\
Net Worth & 122 & 42 \\
Fixed Charge Coverage & 114 & 35 \\
Cash Flow Coverage & 87 & 37 \\
Debt to Equity & 76 & 27 \\
Cash Flow to Debt Service & 72 & 30 \\
Tangible Net Worth & 72 & 20 \\
Debt Service Coverage & 61 & 20 \\
EBITDA & 46 & 20 \\
Cash Balance & 41 & 18 \\
Loan to Value & 22 & 6 \\
Trade Receivables Cover & 20 & 9 \\
Net Debt & 15 & 6 \\
Profit & 15 & 5 \\
Debt to Tangible Net Worth & 9 & 3 \\
Sales Level & 7 & 3 \\
Current Ratio & 5 & 3 \\
Debt to Fair Value & 5 & 1 \\
Senior Notes & 5 & 3 \\
EBITDA to Net Debt & 4 & 3 \\
Trade Receivables to Net Debt & 2 & 3 \\
\hline Notes & 76 & 3 \\
\hline
\end{tabular}

Notes

This table reports the summary of debt covenant restrictions (sample period: 2005-2014) in the UK obtained from the company annual reports. 
Table 2

Summary statistics

Panel A: Descriptive statistics for the full sample

\begin{tabular}{|c|c|c|c|c|c|}
\hline & (1) & (2) & (3) & $\begin{array}{l}\text { (3) } \\
7^{\text {th }}\end{array}$ & $\begin{array}{c}\text { (5) } \\
\text { (td }\end{array}$ \\
\hline Variables & Mean & $25^{\text {th }}$ & Median & $75^{\text {th }}$ & Std. Dev \\
\hline$U E_{-} O R_{i, t}$ & -0.002 & -0.083 & -0.006 & 0.068 & 0.157 \\
\hline$N O R_{i, t}$ & 0.013 & 0.001 & 0.003 & 0.012 & 0.026 \\
\hline$T I G H T_{-} I C \_S L A C K_{i, t}$ & 0.333 & 0.000 & 0.000 & 1.000 & 0.472 \\
\hline$I C \_S L A C K_{i, t}$ & 3.031 & 0.870 & 1.778 & 3.535 & 4.554 \\
\hline$I C \_C O V_{i, t}$ & 3.443 & 3.000 & 3.500 & 4.000 & 0.774 \\
\hline$A_{-} C F O_{i, t}$ & 0.015 & -0.023 & 0.009 & 0.048 & 0.067 \\
\hline$A \_D I S X_{i, t}$ & -0.041 & -0.137 & -0.051 & 0.052 & 0.147 \\
\hline$A_{-} P R O D_{i, t}$ & 0.017 & -0.074 & 0.033 & 0.110 & 0.175 \\
\hline$A_{-} W C A_{i, t}$ & 0.003 & -0.044 & 0.007 & 0.051 & 0.115 \\
\hline$C S_{i, t}$ & 0.383 & 0.000 & 0.000 & 1.000 & 0.487 \\
\hline$D I S T_{i, t-1}$ & 3.918 & 1.140 & 3.710 & 6.700 & 4.872 \\
\hline $\operatorname{LOSS}_{i, t}$ & 0.145 & 0.000 & 0.000 & 0.000 & 0.352 \\
\hline$S I Z E_{i, t}$ & 0.333 & 0.000 & 0.000 & 1.000 & 0.472 \\
\hline Observations & \multicolumn{5}{|c|}{559} \\
\hline
\end{tabular}

Panel B: Descriptive statistics for firms with tight and loose covenant slack

\begin{tabular}{|c|c|c|c|c|c|c|}
\hline \multirow[b]{2}{*}{ Variables } & \multicolumn{2}{|c|}{$\begin{array}{l}\text { Firms with tight } \\
\text { covenant slack }\end{array}$} & \multicolumn{2}{|c|}{$\begin{array}{l}\text { Firms with loose } \\
\text { covenant slack }\end{array}$} & \multicolumn{2}{|c|}{ Difference in } \\
\hline & Mean & Median & Mean & Median & $\begin{array}{l}\text { Means } \\
(t \text {-test })\end{array}$ & $\begin{array}{c}\text { Medians } \\
\text { (Wilcoxon test) }\end{array}$ \\
\hline$U E_{-} O R_{i, t}$ & -0.023 & -0.028 & 0.008 & 0.003 & $* *$ & $* * *$ \\
\hline$N O R_{i, t}$ & 0.018 & 0.006 & 0.011 & 0.003 & $* * *$ & **** \\
\hline$I C \_S L A C K_{i, t}$ & 0.419 & 0.611 & 4.333 & 2.771 & $* * *$ & **** \\
\hline$I C \_C O V_{i, t}$ & 3.465 & 3.500 & 3.432 & 3.250 & & \\
\hline$A_{-} C F O_{i, t}$ & 0.003 & 0.002 & 0.022 & 0.012 & $* * *$ & $* * *$ \\
\hline$A \_D I S X_{i, t}$ & -0.037 & -0.059 & -0.043 & -0.049 & & \\
\hline$A \_P R O D_{i, t}$ & 0.041 & 0.051 & 0.005 & 0.025 & $* *$ & $* * * *$ \\
\hline$A_{-} W C A_{i, t}$ & 0.005 & 0.005 & 0.003 & 0.009 & & \\
\hline$C S_{i, t}$ & 0.398 & 0.000 & 0.375 & 0.000 & & \\
\hline$D I S T_{i, t-1}$ & 2.362 & 1.995 & 4.693 & 4.490 & $* * *$ & $* * *$ \\
\hline $\operatorname{LOSS}_{i, t}$ & 0.296 & 0.000 & 0.070 & 0.000 & $* * *$ & \\
\hline$S I Z E_{i, t}$ & 0.387 & 0.000 & 0.306 & 0.000 & $*$ & \\
\hline Observations & \multicolumn{2}{|c|}{186} & \multicolumn{2}{|c|}{373} & & \\
\hline
\end{tabular}

\section{Notes}

This table shows the descriptive statistics of the variables used in the study. Panels A and B indicate the descriptive statistics of the main variables for the full sample and the firms with tight and loose interest coverage covenant slack, respectively. $U E_{-} O R_{i, t}$ is unexpected operating revenues. $N O R_{i, t}$ is non-operating revenues. $T I G H T \_I C \_S L A C K_{i, t}$ is equal to one for firms with tight interest coverage covenant slack, and zero otherwise. $I C \_S L A C K_{i, t}$ is the interest coverage covenant slack. $I C \_C O V_{i, t}$ is the interest coverage covenant threshold. $A_{-}$ $C F O_{i, t}$ is abnormal levels of cash flows from operations. $A_{-} D I S X_{i, t}$ is abnormal levels of discretionary expenses. $A_{-} P R O D_{i, t}$ is abnormal levels of production costs. $A_{-} W C A_{i, t}$ is abnormal levels of working capital accruals. $C S_{i, t}$ 
is equal to one for firms that have positive unexpected core earnings and income-decreasing special items, and zero otherwise. $D I S T_{i, t-l}$ is the Taffler Z-score. $\operatorname{LOSS}_{i, t}$ is equal to one for firm-years that have losses, and zero otherwise. $S I Z E_{i, t}$ is equal to one for firms that have a natural logarithm of sales revenue within the top tercile of the full sample, and zero otherwise. ${ }^{* * * * * * * *}$ indicate significance at 1\%/5\%/10\% (two tailed) levels, respectively. 
Table 3

Pearson correlation matrix

\begin{tabular}{|c|c|c|c|c|c|c|c|c|c|c|}
\hline Variables & $U E \_O R_{i, t}$ & $N O R_{i, t}$ & $\begin{array}{c}T I G H T_{-} \\
I C \_S L A C K_{i, t}\end{array}$ & $A \_C F O_{i, t}$ & $A \_D I S X_{i, t}$ & $A \_P R O D_{i, t}$ & $A_{-} W C A_{i, t}$ & $C S_{i, t}$ & $D I S T_{i, t-1}$ & $\operatorname{LOSS}_{i, t}$ \\
\hline \multicolumn{11}{|l|}{$U E \_O R_{i, t}$} \\
\hline$N O R_{i, t}$ & -0.197 & & & & & & & & & \\
\hline$T I G H T_{-} I C \_S L A C K_{i, t}$ & -0.092 & 0.125 & & & & & & & & \\
\hline$A \_C F O_{i, t}$ & 0.021 & 0.021 & -0.135 & & & & & & & \\
\hline$A \_D I S X_{i, t}$ & 0.040 & -0.051 & 0.020 & -0.053 & & & & & & \\
\hline$A \_P R O D_{i, t}$ & 0.111 & 0.024 & 0.095 & -0.316 & -0.604 & & & & & \\
\hline$A \_W C A_{i, t}$ & -0.002 & 0.067 & 0.008 & -0.084 & 0.013 & 0.029 & & & & \\
\hline$C S_{i, t}$ & -0.109 & 0.069 & 0.022 & -0.014 & -0.104 & -0.104 & 0.008 & & & \\
\hline$D I S T_{i, t-1}$ & -0.036 & 0.007 & -0.226 & 0.262 & 0.019 & -0.114 & -0.155 & -0.109 & & \\
\hline $\operatorname{LOSS}_{i, t}$ & -0.083 & 0.014 & 0.303 & -0.180 & 0.020 & 0.046 & -0.027 & 0.188 & -0.160 & \\
\hline$S I Z E_{i, t}$ & 0.012 & 0.044 & 0.081 & -0.004 & -0.053 & 0.077 & -0.012 & 0.045 & -0.072 & -0.021 \\
\hline
\end{tabular}

Notes

This table shows the Pearson correlations among regression variables for the full sample. $U E_{-} O R_{i, t}$ is unexpected operating revenues. $N O R_{i, t}$ is non-operating revenues. TIGHT_IC_SLACK $K_{i, t}$ is equal to one for firms with tight interest coverage covenant slack, and zero otherwise. $A_{-} C F O_{i, t}$ is abnormal levels of cash flows from operations. $A_{-} D I S X_{i, t}$ is abnormal levels of discretionary expenses. $A_{-} P R O D_{i, t}$ is abnormal levels of production costs. $A_{-} W C A_{i, t}$ is abnormal levels of working capital accruals. $C S_{i, t}$ is equal to one for firms that have positive unexpected core earnings and income-decreasing special items, and zero otherwise. $D I S T_{i, t-1}$ is the Taffler Z-score. $L O S S_{i, t}$ is equal to one for firm-years that have losses, and zero otherwise. $S I Z E_{i, t}$ is equal to one for firms that have a natural logarithm of sales revenue within the top tercile of the full sample, and zero otherwise. Amounts in bold are significant at 0.05 level. 
Table 4

The effect of tight covenant slack on classification shifting of revenues

\begin{tabular}{|c|c|}
\hline Variables & $U E_{-} O R_{i, t}$ \\
\hline$N O R_{i, t}$ & $\begin{array}{l}-0.771 * \\
(-1.717)\end{array}$ \\
\hline$T I G H T_{-} I C \_S L A C K_{i, t}$ & $\begin{array}{c}-0.014 \\
(-0.671)\end{array}$ \\
\hline$N O R_{i, t} \times T I G H T_{-} I C \_S L A C K_{i, t}$ & $\begin{array}{r}-1.270 * * \\
(-2.116)\end{array}$ \\
\hline$A_{-} C F O_{i, t}$ & $\begin{array}{c}0.144 \\
(0.751)\end{array}$ \\
\hline$N O R_{i, t} \times A \_C F O_{i, t}$ & $\begin{array}{l}7.151 * * \\
(2.104)\end{array}$ \\
\hline$A \_D I S X_{i, t}$ & $\begin{array}{r}0.217 * * \\
(2.453)\end{array}$ \\
\hline$N O R_{i, t} \times A \_D I S X_{i, t}$ & $\begin{array}{c}-0.105 \\
(-0.039)\end{array}$ \\
\hline$A \_P R O D_{i, t}$ & $\begin{array}{l}0.203 * * \\
(2.317)\end{array}$ \\
\hline$N O R_{i, t} \times A_{-} P R O D_{i, t}$ & $\begin{array}{r}4.258 * * \\
(2.121)\end{array}$ \\
\hline$A_{-} W C A_{i, t}$ & $\begin{array}{c}0.005 \\
(0.055)\end{array}$ \\
\hline$N O R_{i, t} \times A_{-} W C A_{i, t}$ & $\begin{array}{l}-1.066 \\
(-0.552)\end{array}$ \\
\hline$C S_{i, t}$ & $\begin{array}{l}-0.007 \\
(-0.447)\end{array}$ \\
\hline$N O R_{i, t} \times C S_{i, t}$ & $\begin{array}{c}-0.424 \\
(-0.716)\end{array}$ \\
\hline$D I S T_{i, t-1}$ & $\begin{array}{c}-0.003 \\
(-1.357)\end{array}$ \\
\hline$N O R_{i, t} \times D I S T_{i, t-1}$ & $\begin{array}{l}-0.040 \\
(-0.661)\end{array}$ \\
\hline$L O S S_{i, t}$ & $\begin{array}{c}-0.021 \\
(-0.924)\end{array}$ \\
\hline$N O R_{i, t} \times L_{O S S_{i, t}}$ & $\begin{array}{l}-0.459 \\
(-0.698)\end{array}$ \\
\hline$S I Z E_{i, t}$ & $\begin{array}{c}-0.011 \\
(-0.619)\end{array}$ \\
\hline$N O R_{i, t} \times S I Z E_{i, t}$ & $\begin{array}{l}1.254^{*} \\
(1.719)\end{array}$ \\
\hline Constant & $\begin{array}{c}0.052 \\
(0.908)\end{array}$ \\
\hline Year dummies & Yes \\
\hline Observations & 559 \\
\hline F-test & $5.62 * * *$ \\
\hline Adjusted R-squared & 0.103 \\
\hline
\end{tabular}

\section{Notes}

This table shows regression results for examining whether firms engage in classification shifting of revenues when they have tight interest coverage covenant slack. $U E_{-} O R_{i, t}$ is unexpected operating revenues. $N O R_{i, t}$ is non-operating revenues. $T I G H T \_I C \_S L A C K_{i, t}$ is equal to one for firms with tight interest coverage covenant slack, and zero otherwise. $A \_C F O_{i, t}$ is abnormal levels of cash flows from operations. $A \_D I S X_{i, t}$ is abnormal levels of discretionary expenses. $A \_P R O D_{i, t}$ is abnormal levels 
of production costs. $A_{-} W C A_{i, t}$ is abnormal levels of working capital accruals. $C S_{i, t}$ is equal to one for firms that have positive unexpected core earnings and incomedecreasing special items, and zero otherwise. DIST $T_{i, t-1}$ is the Taffler Z-score. $\operatorname{LOSS}_{i, t}$ is equal to one for firm-years that have losses, and zero otherwise. $S I Z E_{i, t}$ is equal to one for firms that have a natural logarithm of sales revenue within the top tercile of the full sample, and zero otherwise. $t$-statistics (in parentheses) based on robust standard errors clustered by firm. ${ }^{* * * * * * * *}$ indicate significance at $1 \% / 5 \% / 10 \%$ (two tailed) levels, respectively. 
Table 5

Other EBITDA-related covenant measures

\begin{tabular}{|c|c|c|}
\hline Variables & $U E_{-} O R_{i, t}$ & $U E_{-} O R_{i, t}$ \\
\hline$N O R_{i, t}$ & $\begin{array}{l}0.922 * * * \\
(2.736)\end{array}$ & $\begin{array}{c}0.037 \\
(0.059)\end{array}$ \\
\hline$E B I T D A \_A L L_{i, t}$ & $\begin{array}{l}0.031 * * \\
(2.313)\end{array}$ & \\
\hline$N O R_{i, t} \times E B I T D A \_A L L_{i, t}$ & $\begin{array}{c}-1.566 * * * \\
(-3.603)\end{array}$ & \\
\hline$T I G H T_{-} D E \_S L A C K_{i, t}$ & & $\begin{array}{c}0.005 \\
(0.254)\end{array}$ \\
\hline$N O R_{i, t} \times T I G H T_{-} D E_{-} S L A C K_{i, t}$ & & $\begin{array}{c}-1.256^{* *} \\
(-2.004)\end{array}$ \\
\hline$A \_C F O_{i, t}$ & $\begin{array}{c}0.119 \\
(0.993)\end{array}$ & $\begin{array}{c}0.131 \\
(0.650)\end{array}$ \\
\hline$N O R_{i, t} \times A \_C F O_{i, t}$ & $\begin{array}{c}1.291 \\
(0.567)\end{array}$ & $\begin{array}{c}13.626 * * * \\
(3.346)\end{array}$ \\
\hline$A \_D I S X_{i, t}$ & $\begin{array}{c}0.184 * * * \\
(3.244)\end{array}$ & $\begin{array}{c}0.205^{* *} \\
(2.259)\end{array}$ \\
\hline$N O R_{i, t} \times A \_D I S X_{i, t}$ & $\begin{array}{l}3.470 * * \\
(2.111)\end{array}$ & $\begin{array}{c}3.788 \\
(1.009)\end{array}$ \\
\hline$A \_P R O D_{i, t}$ & $\begin{array}{l}0.124 * * \\
(2.314)\end{array}$ & $\begin{array}{c}0.130 \\
(1.522)\end{array}$ \\
\hline$N O R_{i, t} \times A \_P R O D_{i, t}$ & $\begin{array}{l}4.131 * * * \\
(2.806)\end{array}$ & $\begin{array}{l}10.375 * * * \\
(4.079)\end{array}$ \\
\hline$A_{-} W C A_{i, t}$ & $\begin{array}{l}-0.013 \\
(-0.293)\end{array}$ & $\begin{array}{l}-0.136 \\
(-1.426)\end{array}$ \\
\hline$N O R_{i, t} \times A_{-} W C A_{i, t}$ & $\begin{array}{l}-0.831 \\
(-0.827)\end{array}$ & $\begin{array}{l}5.620 * * \\
(2.204)\end{array}$ \\
\hline$C S_{i, t}$ & $\begin{array}{c}-0.013 \\
(-1.102)\end{array}$ & $\begin{array}{c}-0.011 \\
(-0.713)\end{array}$ \\
\hline$N O R_{i, t} \times C S_{i, t}$ & $\begin{array}{c}-0.408 \\
(-0.882)\end{array}$ & $\begin{array}{c}-0.969 \\
(-1.481)\end{array}$ \\
\hline$D I S T_{i, t-1}$ & $\begin{array}{l}-0.002 * * \\
(-2.033)\end{array}$ & $\begin{array}{c}-0.002 \\
(-0.942)\end{array}$ \\
\hline$N O R_{i, t} \times D I S T_{i, t-l}$ & $\begin{array}{l}-0.026 \\
(-0.905)\end{array}$ & $\begin{array}{l}-0.061 \\
(-0.842)\end{array}$ \\
\hline $\operatorname{LOSS}_{i, t}$ & $\begin{array}{c}-0.015 \\
(-0.926)\end{array}$ & $\begin{array}{c}-0.027 \\
(-1.153)\end{array}$ \\
\hline$N O R_{i, t} \times L O S S_{i, t}$ & $\begin{array}{c}-0.496 \\
(-0.991)\end{array}$ & $\begin{array}{l}-1.035 \\
(-1.604)\end{array}$ \\
\hline$S I Z E_{i, t}$ & $\begin{array}{c}0.000 \\
(0.026)\end{array}$ & $\begin{array}{c}0.009 \\
(0.525)\end{array}$ \\
\hline$N O R_{i, t} \times S I Z E_{i, t}$ & $\begin{array}{c}0.509 \\
(0.833)\end{array}$ & $\begin{array}{c}0.201 \\
(0.258)\end{array}$ \\
\hline Constant & $\begin{array}{l}0.064 * \\
(1.710)\end{array}$ & $\begin{array}{c}0.044 \\
(0.646)\end{array}$ \\
\hline Year dummies & Yes & Yes \\
\hline Observations & 1,272 & 502 \\
\hline F-test & $3.81 * * *$ & $6.34 * * *$ \\
\hline Adjusted R-squared & 0.064 & 0.111 \\
\hline
\end{tabular}

Notes

Columns (1) and (2) show regression results for examining whether firms engage in classification shifting of revenues when they have only EBITDA-related covenants and tight debt to EBITDA covenant slack, respectively. $U E_{-} O R_{i, t}$ is unexpected operating revenues. $N O R_{i, t}$ is non-operating revenues. EBITDA_ALL 
is equal to one for firms that have only EBITDA-related covenants, and zero otherwise. $T I G H T \_D E \_S L A C K_{i, t}$ is equal to one for firms with tight debt to EBITDA covenant slack, and zero otherwise. A_CFO $O_{i, t}$ is abnormal levels of cash flows from operations. A_DISX $X_{i, t}$ is abnormal levels of discretionary expenses. $A \_P R O D_{i, t}$ is abnormal levels of production costs. $A_{-} W C A_{i, t}$ is abnormal levels of working capital accruals. $C S_{i, t}$ is equal to one for firms that have positive unexpected core earnings and income-decreasing special items, and zero otherwise. $D I S T_{i, t-l}$ is the Taffler Z-score. $L O S S_{i, t}$ is equal to one for firm-years that have losses, and zero otherwise. $S I Z E_{i, t}$ is equal to one for firms that have a natural logarithm of sales revenue within the top tercile of the full sample, and zero otherwise. $t$-statistics (in parentheses) based on robust standard errors clustered by firm. ${ }^{* * * * * * *}$ indicate significance at $1 \% / 5 \% / 10 \%$ (two tailed) levels, respectively. 
Table 6

\section{Controlling for corporate governance}

\begin{tabular}{|c|c|}
\hline Variable & $U E_{-} O R_{i, t}$ \\
\hline$N O R_{i, t}$ & $\begin{array}{l}-0.827 * * \\
(-2.073)\end{array}$ \\
\hline$T I G H T_{-} I C_{-} S L A C K_{i, t}$ & $\begin{array}{c}-0.012 \\
(-0.561)\end{array}$ \\
\hline$N O R_{i, t} \times T I G H T_{-} I C \_S L A C K_{i, t}$ & $\begin{array}{c}-1.745 * * * \\
(-2.809)\end{array}$ \\
\hline$A U D C_{i, t}$ & $\begin{array}{c}0.001 \\
(0.056)\end{array}$ \\
\hline$N O R_{i, t} \times A U D C_{i, t}$ & $\begin{array}{c}1.384 * * \\
(2.458)\end{array}$ \\
\hline$B I N D_{i, t}$ & $\begin{array}{c}0.006 \\
(0.367)\end{array}$ \\
\hline$N O R_{i, t} \times B I N D_{i, t}$ & $\begin{array}{c}-0.635 \\
(-1.247)\end{array}$ \\
\hline$A_{-} C F O_{i, t}$ & $\begin{array}{c}0.136 \\
(0.704)\end{array}$ \\
\hline$N O R_{i, t} \times A_{-} C F O_{i, t}$ & $\begin{array}{c}10.869 * * * \\
(3.271)\end{array}$ \\
\hline$A \_D I S X_{i, t}$ & $\begin{array}{c}0.208 * * \\
(2.386)\end{array}$ \\
\hline$N O R_{i, t} \times A \_D I S X_{i, t}$ & $\begin{array}{l}1.655 \\
(0.762)\end{array}$ \\
\hline$A \_P R O D_{i, t}$ & $\begin{array}{c}0.190 * * \\
(2.248)\end{array}$ \\
\hline$N O R_{i, t} \times A \_P R O D_{i, t}$ & $\begin{array}{l}5.475 * * * \\
(3.150)\end{array}$ \\
\hline$A_{-} W C A_{i, t}$ & $\begin{array}{c}0.013 \\
(0.155)\end{array}$ \\
\hline$N O R_{i, t} \times A_{-} W C A_{i, t}$ & $\begin{array}{l}-2.192 \\
(-1.389)\end{array}$ \\
\hline$C S_{i, t}$ & $\begin{array}{l}-0.009 \\
(-0.593)\end{array}$ \\
\hline$N O R_{i, t} \times C S_{i, t}$ & $\begin{array}{c}-0.319 \\
(-0.594)\end{array}$ \\
\hline$D I S T_{i, t-1}$ & $\begin{array}{l}-0.003 \\
(-1.322)\end{array}$ \\
\hline$N O R_{i, t} \times D I S T_{i, t-1}$ & $\begin{array}{l}-0.071 \\
(-1.140)\end{array}$ \\
\hline $\operatorname{LOSS}_{i, t}$ & $\begin{array}{l}-0.021 \\
(-0.959)\end{array}$ \\
\hline$N O R_{i, t} \times L_{O S S}$, & $\begin{array}{c}-0.357 \\
(-0.560)\end{array}$ \\
\hline$S I Z E_{i, t}$ & $\begin{array}{c}-0.011 \\
(-0.614)\end{array}$ \\
\hline$N O R_{i, t} \times S I Z E_{i, t}$ & $\begin{array}{l}1.256^{*} \\
(1.750)\end{array}$ \\
\hline Constant & $\begin{array}{c}0.050 \\
(0.850)\end{array}$ \\
\hline Year dummies & Yes \\
\hline Observations & 559 \\
\hline F-test & $8.55 * * *$ \\
\hline Adjusted R-squared & 0.108 \\
\hline
\end{tabular}

Notes 
This table shows regression results for our main analysis after controlling for corporate governance. $U E_{-} O R_{i, t}$ is unexpected operating revenues. $N O R_{i, t}$ is nonoperating revenues. TIGHT_IC_SLACK $K_{i, t}$ is equal to one for firms with tight interest coverage covenant slack, and zero otherwise. $A U D C_{i, t}$ is equal to one if the size of the audit committee is greater than the sample median and all directors on the audit committee are independent, and zero otherwise. $B I N D_{i, t}$ is equal to one if the percentage of independent board members is more than the sample median, and zero otherwise. $A \_C F O_{i, t}$ is abnormal levels of cash flows from operations. $A \_D I S X_{i, t}$ is abnormal levels of discretionary expenses. $A_{-} P R O D_{i, t}$ is abnormal levels of production costs. $A_{-} W C A_{i, t}$ is abnormal levels of working capital accruals. $C S_{i, t}$ is equal to one for firms that have positive unexpected core earnings and incomedecreasing special items, and zero otherwise. $D I S T_{i, t-l}$ is the Taffler Z-score. $L O S S_{i, t}$ is equal to one for firm-years that have losses, and zero otherwise. $S I Z E_{i, t}$ is equal to one for firms that have a natural logarithm of sales revenue within the top tercile of the full sample, and zero otherwise. $t$-statistics (in parentheses) based on robust standard errors clustered by firm. ${ }^{* * * * * * *}$ indicate significance at $1 \% / 5 \% / 10 \%$ (two tailed) levels, respectively. 
Table 7

Excluding financial crisis period

\begin{tabular}{|c|c|}
\hline Variables & $U E_{-} O R_{i, t}$ \\
\hline$N O R_{i, t}$ & $\begin{array}{c}-0.932 \\
(-1.498)\end{array}$ \\
\hline$T I G H T_{-} I C \_S L A C K_{i, t}$ & $\begin{array}{c}0.020 \\
(0.844)\end{array}$ \\
\hline$N O R_{i, t} \times T I G H T_{-} I C \_S L A C K_{i, t}$ & $\begin{array}{c}-1.704 * * \\
(-2.355)\end{array}$ \\
\hline$A_{-} C F O_{i, t}$ & $\begin{array}{c}0.053 \\
(0.240)\end{array}$ \\
\hline$N O R_{i, t} \times A \_C F O_{i, t}$ & $\begin{array}{c}5.077 \\
(1.100)\end{array}$ \\
\hline$A \_D I S X_{i, t}$ & $\begin{array}{c}0.168 \\
(1.651)\end{array}$ \\
\hline$N O R_{i, t} \times A \_D I S X_{i, t}$ & $\begin{array}{c}-1.838 \\
(-0.550)\end{array}$ \\
\hline$A_{-} P R O D_{i, t}$ & $\begin{array}{l}0.183^{*} \\
(1.849)\end{array}$ \\
\hline$N O R_{i, t} \times A_{-} P R O D_{i, t}$ & $\begin{array}{c}1.974 \\
(0.597)\end{array}$ \\
\hline$A_{-} W C A_{i, t}$ & $\begin{array}{c}-0.026 \\
(-0.260)\end{array}$ \\
\hline$N O R_{i, t} \times A_{-} W C A_{i, t}$ & $\begin{array}{c}1.436 \\
(0.589)\end{array}$ \\
\hline$C S_{i, t}$ & $\begin{array}{c}-0.003 \\
(-0.195)\end{array}$ \\
\hline$N O R_{i, t} \times C S_{i, t}$ & $\begin{array}{c}-0.676 \\
(-0.954)\end{array}$ \\
\hline$D I S T_{i, t-1}$ & $\begin{array}{c}-0.002 \\
(-0.965)\end{array}$ \\
\hline$N O R_{i, t} \times D I S T_{i, t-I}$ & $\begin{array}{c}0.001 \\
(0.012)\end{array}$ \\
\hline$L O S S_{i, t}$ & $\begin{array}{c}-0.027 \\
(-0.905)\end{array}$ \\
\hline$N O R_{i, t} \times L O S S_{i, t}$ & $\begin{array}{c}-0.343 \\
(-0.428)\end{array}$ \\
\hline$S I Z E_{i, t}$ & $\begin{array}{c}-0.012 \\
(-0.597)\end{array}$ \\
\hline$N O R_{i, t} \times S I Z E_{i, t}$ & $\begin{array}{c}1.045 \\
(1.404)\end{array}$ \\
\hline Constant & $\begin{array}{c}0.044 \\
(0.755)\end{array}$ \\
\hline Year dummies & Yes \\
\hline Observations & 424 \\
\hline F-test & $4.08 * * *$ \\
\hline Adjusted R-squared & 0.107 \\
\hline
\end{tabular}

\section{Notes}

This table shows regression results for our main analysis after excluding financial crisis period. $U E_{-} O R_{i, t}$ is unexpected operating revenues. $N O R_{i, t}$ is non-operating revenues. TIGHT_IC_SLACK $K_{i, t}$ is equal to one for firms with tight interest coverage covenant slack, and zero otherwise. $A \_C F O_{i, t}$ is abnormal levels of cash flows from operations. $A \_D I S X_{i, t}$ is abnormal levels of discretionary expenses. $A_{-} P R O D_{i, t}$ is abnormal levels of production costs. $A_{-} W C A_{i, t}$ is abnormal levels of working capital accruals. $C S_{i, t}$ is equal to one for firms that 
have positive unexpected core earnings and income-decreasing special items, and zero otherwise. $D I S T_{i, t-1}$ is the Taffler Z-score. $\operatorname{LOSS}_{i, t}$ is equal to one for firm-years that have losses, and zero otherwise. $S I Z E_{i, t}$ is equal to one for firms that have a natural logarithm of sales revenue within the top tercile of the full sample, and zero otherwise. $t$-statistics (in parentheses) based on robust standard errors clustered by firm. ${ }^{* * * * * * * *}$ indicate significance at $1 \% / 5 \% / 10 \%$ (two tailed) levels, respectively. 
Appendix 1. The illustrative format of the income statement

Sales Revenue

Operating Revenues - Other

Cost of Goods Sold

Gross Profit

Selling, General and Administrative Expenses

Operating Expense - Other

EBITDA

Depreciation of Fixed Assets

Amortization of Intangibles

Interest and Related Expense

Non-operating Revenues

- Interest and Dividend Income

- Rental Income

- $\quad$ Special Items

Pretax Income

Income Taxes

Net Income

Notes

This table shows the standard format of the income statement used by the Compustat Global database. 


\section{Appendix 2. Other earnings management measures}

\section{Real earnings management}

Following prior research, three measures for real earnings management are employed (e.g. Franz et al. 2014; Roychowdhury 2006). These are abnormal levels of cash flows from operations (A_CFO), abnormal levels of discretionary expenses $\left(A \_D I S X\right)$, and abnormal levels of production costs $\left(A \_P R O D\right)$. $A \_C F O, A \_D I S X$, and A_PROD are measured as the residuals from the following regressions estimated cross-sectionally for each industry-year, respectively:

$$
\begin{aligned}
& \frac{C F O_{i, t}}{A T_{i, t-1}}=\alpha_{0}+\beta_{1} \frac{1}{A T_{i, t-1}}+\beta_{2} \frac{S_{i, t}}{A T_{i, t-1}}+\beta_{3} \frac{\Delta S_{i, t}}{A T_{i, t-1}}+e_{i, t} \\
& \frac{D I S X_{i, t}}{A T_{i, t-1}}=\alpha_{0}+\beta_{1} \frac{1}{A T_{i, t-1}}+\beta_{2} \frac{S_{i, t-1}}{A T_{i, t-1}}+e_{i, t} \\
& \frac{P R O D_{i, t}}{A T_{i, t-1}}=\alpha_{0}+\beta_{1} \frac{1}{A T_{i, t-1}}+\beta_{2} \frac{S_{i, t}}{A T_{i, t-1}}+\beta_{3} \frac{\Delta S_{i, t}}{A T_{i, t-1}}+\beta_{4} \frac{\Delta S_{i, t-1}}{A T_{i, t-1}}+e_{i, t}
\end{aligned}
$$

where $C F O_{i, t}$ is cash flows from operations for firm $i$ in year $t ; A T_{i, t-1}$ is total assets; $S_{i, t}$ is sales revenue; DISX $X_{i, t}$ is discretionary expenses, calculated as the sum of selling, general, and administrative expenses and R\&D expenses; $P R O D_{i, t}$ is production costs, calculated as the sum of cost of sales and change in inventory.

\section{Accruals earnings management}

Working capital discretionary accruals $\left(A \_W C A\right)$ are used as a measure for accruals earnings management following existing studies (e.g. Dechow and Dichev 2002; Peasnell et al. 2000). A_WCA is measured as the residual from the following regression estimated cross-sectionally for each industry-year:

$$
\frac{W C A_{i, t}}{A T_{i, t-1}}=\alpha_{0}+\beta_{1} \frac{1}{A T_{i, t-1}}+\beta_{2} \frac{\Delta S A_{i, t}}{A T_{i, t-1}}+e_{i, t}
$$

where $W C A_{i, t}$ is working capital accruals for firm $i$ in year $t$, calculated as the change in non-cash current assets minus the change in current liabilities (net of change in the current portion of long term debt); $A T_{i, t-I}$ is total assets; $\Delta S A_{i, t}$ is the change in sales revenue minus the change in accounts receivable.

\section{Classification shifting of expenses}

Extant studies document that if a firm engages in classification shifting of expenses then they are likely to have positive unexpected core earnings and income-decreasing special items (e.g. Fan et al. 2019; Joo and Chamberlain 2017; McVay 2006). Therefore, we measure expense misclassification using an indicator variable, $C S$, that is equal to one for firms that have positive unexpected core earnings and income-decreasing special items and zero 
otherwise where unexpected core earnings are calculated as the residuals from the following regression estimated cross-sectionally for each industry-year:

$$
C E_{i, t}=\alpha_{0}+\beta_{1} C E_{i, t-1}+\beta_{2} A T O_{i, t}+\beta_{3} A C C R_{i, t-1}+\beta_{4} A C C R_{i, t}+\beta_{5} \Delta P S_{i, t}+\beta_{6} N E G_{-} \Delta P S_{i, t}+e_{i, t}
$$

where $C E_{i . t}$ is core earnings for firm $i$ in year $t$ scaled by sales revenue where the former is defined as sales revenue minus cost of sales minus selling, general and administrative expenses; $A T O_{i, t}$ is asset turnover ratio, calculated as sales revenue over average net operating assets; $A C C R_{i, t}$ is accruals, defined as the difference between net income before extraordinary items and cash flows from operations divided by sales revenue; $\triangle P S_{i, t}$ is percentage change in sales revenue; $N E G_{-} \Delta P S_{i, t}$ is percentage change in sales revenue if it is less than zero, and zero otherwise. 


\section{References}

Abernathy, J. L., Beyer, B., \& Rapley, E. T. (2014). Earnings management constraints and classification shifting. Journal of Business, Finance and Accounting, 41(5-6), 600-626.

Acharya, V. V., Sundaram, R. K., \& John, K. (2011). Cross-country variations in capital structures: The role of bankruptcy codes. Journal of Financial Intermediation, 20(1), $25-54$

Athanasakou, V. E., Strong, N. C., \& Walker, M. (2009). Earnings management or forecast guidance to meet analyst expectations? Accounting and Business Research, 39(1), 335.

Beatty, A., Weber, J., \& Yu, J. J. (2008). Conservatism and debt. Journal of Accounting and Economics, 45(2-3), 154-174.

Beccalli, E., Bozzolan, S., Menini, A., \& Molyneux, P. (2015). Earnings management, forecast guidance and the banking crisis. The European Journal of Finance, 21(3), 242-268.

Butler, M., Leone, A. J., \& Willenborg, M. (2004). An empirical analysis of auditor reporting and its association with abnormal accruals. Journal of Accounting and Economics, 37(2), 139-165.

Callen, J. L., Robb, S. W., \& Segal, D. (2008). Revenue manipulation and restatements by loss firms. Auditing: A Journal of Practice and Theory, 27(2), 1-29.

Chatterjee, A. (2006). Performance pricing covenants in debt contracts in the UK. Working paper, University of Cambridge.

Chava, S., \& Roberts, M. R. (2008). How does financing impact investment? The role of debt covenants. The Journal of Finance, 63(5), 2085-2121.

Christensen, H. B., Lee, E., \& Walker, M. (2009). Do IFRS reconciliations convey information? The effect of debt contracting. Journal of Accounting Research, 47(5), 1167-1199. 
Citron, D. B. (1992). Accounting measurement rules in UK bank loan contracts. Accounting and Business Research, 23(89), 21-30.

Cohen, D. A., \& Zarowin, P. (2007). Earnings management over the business cycle. Working paper, New York University.

Day, J., \& Taylor, P. (1996). Loan contracting by UK corporate borrowers. Journal of International Banking Law, 11 (3), 318-326.

Davydenko, S. A., \& Franks, J. R. (2008). Do bankruptcy codes matter? A study of defaults in France, Germany, and the UK. Journal of Finance, 63(2), 565-608.

Deakin, S., Mollica, V., \& Sarkar, P. (2017). Varieties of creditor protection: insolvency law reform and credit expansion in developed market economies. Socio-Economic Review, 15(2), 359-384.

Dechow, P. M., \& Dichev, I. D. (2002). The quality of accruals and earnings: The role of accrual estimation errors. The Accounting Review, 77(s-1), 35-59.

DeFond, M. L., \& Jiambalvo, J. (1994). Debt covenant violation and manipulation of accruals. Journal of Accounting and Economics, 17(1), 145-176.

Demerjian, P. (2011). Accounting standards and debt covenants: Has the balance sheet approach' led to a decline in the use of balance sheet covenants? Journal of Accounting and Economics, 52(2), 178-202.

Demerjian, P. R., \& Owens, E. L. (2016). Measuring the probability of financial covenant violation in private debt contracts. Journal of Accounting and Economics, 61(2-3), 433447.

Denis, D. J., \& Wang, J. (2014). Debt covenant renegotiations and creditor control rights. Journal of Financial Economics, 113(3), 348-367.

Dichev, I. D., \& Skinner, D. J. (2002). Large-sample evidence on the debt covenant hypothesis. Journal of Accounting Research, 40(4), 1091-1123. 
Ertimur, Y., Livnat, J., \& Martikainen, M. (2003). Differential market reactions to revenue and expense surprises. Review of Accounting Studies, 8(2-3), 185-211.

Evans, M. E., Houston, R. W., Peters, M. F., \& Pratt, J. H. (2015). Reporting regulatory environments and earnings management: US and non-US firms using US GAAP or IFRS. The Accounting Review, 90(5), 1969-1994.

Fan, Y., Barua, A., Cready, W. M., \& Thomas, W. B. (2010). Managing earnings using classification shifting: Evidence from quarterly special items. The Accounting Review, 85(4), 1303-1323.

Fan, Y., \& Liu, X. K. (2017). Misclassifying core expenses as special items: cost of goods sold or selling, general, and administrative expenses? Contemporary Accounting Research, 34(1), 400-426.

Fan, Y., Thomas, W. B., \& Yu, X. S. (2019). The impact of financial covenants in private loan contracts on classification shifting. Management Science. Forthcoming.

Franz, D. R., HassabElnaby, H. R., \& Lobo, G. J. (2014). Impact of proximity to debt covenant violation on earnings management. Review of Accounting Studies, 19(1), 473-505.

Godlewski, C. J. (2015). The certification value of private debt renegotiation and the design of financial contracts: Empirical evidence from Europe. Journal of Banking and Finance, 53, 1-17.

Gunny, K. A. (2010). The relation between earnings management using real activities manipulation and future performance: Evidence from meeting earnings benchmarks. Contemporary Accounting Research, 27(3), 855-888.

Hsu, C., \& Kross, W. (2011). The market pricing of special items that are included in versus excluded from street earnings. Contemporary Accounting Research, 28(3), 990-1017. 
Jacoby, G., Li, J., \& Liu, M. (2019). Financial distress, political affiliation and earnings management: the case of politically affiliated private firms. The European Journal of Finance, 25(6), 508-523.

Joo, J. H., \& Chamberlain, S. L. (2017). The Effects of governance on classification shifting and compensation shielding. Contemporary Accounting Research, 34(4), 1779-1811.

Kama, I. (2004). Revenues and earnings as key value drivers in various contexts: implications for financial management and statement analysis. Working paper, London Business School.

Kim, B., Lisic, L. L., \& Pevzner, M. (2010). Debt covenant slacks and real earnings management. Working paper, George Mason University.

Klein, A. (2002). Audit committee, board of director characteristics, and earnings management. Journal of Accounting and Economics, 33(3), 375-400.

Kousenidis, D. V., Ladas, A. C., \& Negakis, C. I. (2013). The effects of the European debt crisis on earnings quality. International Review of Financial Analysis, 30, 351-362.

Li, N. (2016). Performance measures in earnings-based financial covenants in debt contracts. Journal of Accounting Research, 54(4), 1149-1186.

Li, N., Lou, Y., \& Vasvari, F. P. (2015). Default clauses in debt contracts. Review of Accounting Studies, 20(4), 1596-1637.

Lin, J. W., \& Hwang, M. I. (2010). Audit quality, corporate governance, and earnings management: A meta-analysis. International Journal of Auditing, 14(1), 57-77.

Malikov, K., Manson, S., \& Coakley, J. (2018). Earnings management using classification shifting of revenues. The British Accounting Review, 50(3), 291-305.

Marquardt, C. A., \& Wiedman, C. I. (2004). How are earnings managed? An examination of specific accruals. Contemporary Accounting Research, 21(2), 461-491. 
Marshall, A., McCann, L., \& McColgan, P. (2019). The market reaction to debt announcements: UK evidence surrounding the global financial crisis. The British Accounting Review, 51(1), 92-109.

McVay, S. E. (2006). Earnings management using classification shifting: an examination of core earnings and special items. The Accounting Review, 81(3), 501-531.

Moir, L., \& Sudarsanam, S. (2007). Determinants of financial covenants and pricing of debt in private debt contracts: The UK evidence. Accounting and Business Research, 37(2), $151-166$

Nagar, N., \& Sen, K. (2016). Earnings management in India: Managers' fixation on operating profits. Journal of International Accounting, Auditing and Taxation, 26, 1-12.

Nini, G., Smith, D. C., \& Sufi, A. (2012). Creditor control rights, corporate governance, and firm value. The Review of Financial Studies, 25(6), 1713-1761.

Peasnell, K. V., Pope, P. F., \& Young, S. (2000). Accrual management to meet earnings targets: UK evidence pre-and post-Cadbury. The British Accounting Review, 32(4), 415-445

Peasnell, K. V., Pope, P. F., \& Young, S. (2005). Board monitoring and earnings management: Do outside directors influence abnormal accruals? Journal of Business, Finance and Accounting, 32(7-8), 1311-1346.

Petersen, M. A. (2009). Estimating standard errors in finance panel data sets: Comparing approaches. Review of Financial Studies, 22(1), 435-480.

Rhodes, A. (2016). The relation between earnings-based measures in firm debt contracts and CEO pay sensitivity to earnings. Journal of Accounting and Economics, 61(1), 1-22.

Roberts, M. R., \& Sufi, A. (2009). Control rights and capital structure: An empirical investigation. Journal of Finance, 64(4), 1657-1695.

Roychowdhury, S. (2006). Earnings management through real activities manipulation. Journal of Accounting and Economics, 42(3), 335-370. 
Seetharaman, A., Gul, F. A., \& Lynn, S. G. (2002). Litigation risk and audit fees: Evidence from UK firms cross-listed on US markets. Journal of Accounting and Economics, 33(1), 91-115.

Sloan, R. (1996). Do stock prices fully reflect information in accruals and cash flows about future earnings? The Accounting Review, 71(3), 289-315.

Sweeney, A. P. (1994). Debt-covenant violations and managers' accounting responses. Journal of Accounting and Economics, 17(3), 281-308.

Taffler, R. J. (1983). The assessment of company solvency and performance using a statistical model. Accounting and Business Research, 13(52), 295-308.

Taylor, P. (2013). What do we know about the role of financial reporting in debt contracting and debt covenants? Accounting and Business Research, 43(4), 386-417.

Walker, M. (2013). How far can we trust earnings numbers? What research tells us about earnings management. Accounting and Business Research, 43(4), 445-481.

Watts, R., \& Zimmerman, J. (1986). Positive Accounting Theory. Englewood Cliffs, NJ: Prentice-Hall.

Watts, R. L., \& Zimmerman, J. L. (1990). Positive accounting theory: a ten year perspective. Accounting Review, 65(1), 131-156.

Weiss, I. S. (2001). Managerial responses to a transitory earnings shock: strategic manipulation between the core and non-core components of earnings ( $\mathrm{Ph} . \mathrm{D}$ thesis). University of Chicago.

Zalata, A., \& Roberts, C. (2016). Internal corporate governance and classification shifting practices: An analysis of UK corporate behavior. Journal of Accounting, Auditing and Finance, 31(1), 51-78.

Zalata, A. M., \& Roberts, C. (2017). Managing earnings using classification shifting: UK evidence. Journal of International Accounting, Auditing and Taxation, 29, 52-65. 
Zang, A. Y. (2012). Evidence on the trade-off between real activities manipulation and accrualbased earnings management. The Accounting Review, 87(2), 675-703. 